\title{
Dreaming in Canadian: South Asian Youth, Bollywood and Belonging
}

\section{Vinita Srivastava}

Ryerson University

digital.library.ryerson.ca/object/317

Please Cite:

Srivastava, V. (2011). [Review of the book Dreaming in Canadian: South Asian youth, Bollywood and belonging, by F. Hirji]. Global Media Journal - Canadian Edition, 4(2), 129-131.

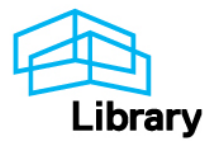




\section{Dreaming in Canadian: South Asian Youth, Bollywood and Belonging}

By Faiza Hirji

Vancouver: UBC Press, 2010. 248 pp.

ISBN: 9780774817981.

A Book Review by

Vinita Srivastava

Ryerson University, Canada

At a recent Toronto red carpet event, Bollywood megastar, Shahrukh Khan answered questions for an intimate crowd of awestruck fans. The questions, shouted out by audience members, came mostly from second generation South Asians who had grown up with Shahrukh Khan's films. Questions took the form of gushing praise-as individuals from the South Asian Diaspora struggled with ways to express their gratitude: "You have meant so much to me-growing up here [in Canada]", said one woman. "Will you please say a line, any line from Kuch Kuch Hota Hai (1998)? It's a movie that has impacted me so much. I cannot even express how much: It changed my life".

It is this profound impact of Bollywood cinema on Canadian youth-their culture and identity - that communication studies scholar Faiza Hirji sets out to examine in her book Dreaming in Canadian: South Asian Youth, Bollywood and Belonging (2010). Hirji's main focus is the interpretation of Bollywood films, and the intersection of ethnicity and religions within these cultural products that she says have significant impact on a young Canadian South Asians and Muslims.

Using firsthand audience accounts, personal reflections and a theoretical framework that draws from media and contemporary race theory scholars, Hirji posits that youth interpretations of Bollywood can be read as possible modes of resistance to dominant media cultures. As well, she suggests Bollywood culture can contribute to identity formation for Canadian youth of the South Asian Diaspora.

The book takes a dialectical approach to the main research questions: the author ruminates through a winding interdisciplinary conversation with scholars about race, media, nation, resistance, aspiration and belonging. Hirji may not have found definitive answers to the questions she set out to explore, yet in examining these issues Hirji's book is a much needed addition to conversations about representation and identity formation - and its implicationswithin Canadian minority ethnic populations. The biggest strength of this book lies in its ability to sift through critical race and media theory and bring to it the voices of racialized youth audiences.

Hirji's research questions have particular resonance in Canada. In selecting her research subjects, Hirji particularly pays attention to South Asian Muslim youth. In a post-9/11 era rife 
with examples of Islamophobia in Canadian civil society, and media it is pertinent to specifically examine media impacts on Muslim youth. As Hirji points out, "popular culture plays a key role in helping the young to understand race, ethnicity and their own relative positionality in society" (2010: 93). As well, the study of media influence on youth identity formation has national significance, as youth can impact the future of civic action and civil society.

Hirji begins her book with a personal reflection on the impact of Bollywood films, mentioning the same film that the adoring Shahrukh fan spoke of-Kuch Kuch Hota Hai. The film, she writes, represented a turning point in Bollywood cinema in that it successfully portrayed a hybrid culture and therefore connected with North American audiences: "It was Indian, but modern” (2010: 3).

Following the lead of sociologist Amita Handa, Hirji rejects the much used culture-clash model to describe the position of South Asians in Canada. Although she occasionally trips over the idea of globalized hybridity. The ideas of modernity as Canadian and tradition as Indian do occur within her discourse. Hirji suggests Bollywood is increasingly aware of as well as economically dependent on its North American diasporic audiences. She sites "revealing western” outfits, English dialogue, and trips to North America and Europe in the plot lines. However, Indian audiences as well as Indian producers play a significant role here: Is Bollywood making films for its own globalized Indian audience or is it making films with a nod to its western diasporic audiences as Hirji suggests? The answer, of course, is complicated. And the author struggles to decipher the intricate connections between a new glocal audience that is indeed, hybrid in its multiple identities and locations.

An understanding of what other media the youth interviewed are consuming would be most helpful. As well, descriptions of film plots, visual language and the political contexts of the time of production in India and Canada would help to place the work into a greater social context.

Following a decade in which the Canadian government supported the idea that Muslim Canadians might be considered a threat to Canadian security, Hirji's book-an astute but subtle examination of the ways that audiences ingest, subvert and reflect culture-refutes such ill and racist stereotypes by offering up complex interviews with South Asian and Muslim Canadian youth that reveal conflicted and complicated stories about media consumption and its impact on identity formation, community, and loneliness in Diaspora.

The book contributes to a growing body of research around the South Asian youth Diaspora in North America, media and race, and racialized audience reception, but it also invites deeper examinations and more studies around media and identity formation. The text could be used in media studies, critical race studies and immigration and settlement courses. You will want to read this if you are interested in popular culture, audience reception, cultural anthropology, or race and ethnicity studies.

\section{About the Reviewer}

Vinita Srivastava is an Assistant Professor at the School of Journalism at Ryerson University, Canada. She specializes in digital media and is the director of Verse City, a multimedia literacy program for marginalized youth. Vinita spent a decade in the New York publishing industry, 
both as a reporter for the alternative media and as an editor for the mainstream media. Her current research examines the impact of hip hop culture on race and representation in the Press from 1993 till 2011 in North America, particularly as it relates to representations of racialized youth.

\section{Citing this book review:}

Srivastava, Vinita. (2011). [Review of the book Dreaming in Canadian: South Asian youth, Bollywood and belonging]. Global Media Journal -- Canadian Edition, 4(2), 129-131. 